\title{
Knowledge on Nutrition Labels for Processed Food: Effect on Purchase Decision among Indonesian Consumers
}

\author{
Anna Vipta Resti Mauludyani ${ }^{1 *}$, Zuraidah Nasution', Muhammad Aries ${ }^{1}$, \\ Rimbawan ${ }^{1}$, Yusra Egayanti ${ }^{2}$
}

${ }^{1}$ Department of Community Nutrition, Faculty of Human Ecology, IPB University, Bogor 16680, Indonesia

${ }^{2}$ Directorate of Processed Food Standardization, Indonesia Food and Drug Authority, Jakarta 10560, Indonesia

\begin{abstract}
This study was conducted to observe the relationship between consumers' knowledge on nutrition labels and the purchasing behavior for processed food products among Indonesian consumers. A crosssectional study was conducted in August-September 2018 in five different cities of three provinces (Jakarta, Bogor, Depok, Tangerang, and Bekasi). Data were obtained from 400 adult consumers by self-administered questionnaires. The results showed that almost $70 \%$ of consumers in Indonesia check food labels; however, from that number only $37.5 \%$ paid attention to the nutrition label of a food product prior to making a purchase decision; this was most probably due to their knowledge on nutrition labels that was still poor, as shown by the mean score of 7.7 out of 14 questions (55\%). In terms of food groups, milk and dairy products were deemed important by the consumers and the nutrition labels were often checked. When it comes to making a purchase decision, almost all of the consumers $(96.0 \%)$ had decided to buy food products with nutrition labels as compared to those without. Furthermore, when compared to similar products also bearing nutrition labels, consumers deemed the claims of low fat $(28.7 \%)$ and low sugar $(22.6 \%)$ as a sign that the products are healthier and have a better nutrition profile. Knowledge on nutrition labels $(\mathrm{OR}=1.139 ; 95 \% \mathrm{CI}: 1.016-1.276 ; \mathrm{p}=0.025)$ and purchase decision on products with nutrition labels $(\mathrm{OR}=3.426 ; 95 \% \mathrm{CI}: 1.220-9.623 ; \mathrm{p}=0.019)$ were significantly associated with purchase decision for healthier processed food. This study has shown the importance of increasing consumers' knowledge on nutrition labels in order to achieve a larger impact on food selection, nutrition, and health.
\end{abstract}

Keywords: consumers knowledge, food label, nutrition claim, nutrition label, purchase behavior

\section{INTRODUCTION}

A consumer's decision to purchase a packaged food product is affected by many aspects i.e. taste, quality, convenience and ease of use. Several other factors have been listed as having the potential to increase the likelihood of purchase i.e. price, perceived healthiness, and tastiness of the product (Steinhauser et al. 2019). One of the aspects that could affect consumer purchase decision are food labels. A food label is an important tool for consumers to get information on the food product that is contained within the package, which eventually might affect their decision in purchasing the product. A study found that some consumers actually put importance on food labels and read them before making final purchase decisions, where the level of importance varied significantly based on gender, age, food habit, and location (Kumar \& Kapoor 2017). However, although $90 \%$ of consumers read food labels, the majority only checked for the manufacturing date or expiry/ best before date (Vemula et al. 2014).

One of the aspects of a food label is nutrition information, which can come in the form of nutrition labels and nutrition and health claims. Of the $90 \%$ of consumers who read food labels, only one-third actually checked nutrition information and ingredients; while those who did not often read nutrition information was due to most consumers either lacking nutrition knowledge or that they found the information to be too technical to understand (Vemula et al. 2014). Similarly, a study found that nutrition information on food labels is often underutilized by consumers and having prior nutrition knowledge would actually help consumers to

"Corresponding Author: tel: +628561164494, email: anna-vipta@apps.ipb.ac.id 
know how to use the information on nutrition labels appropriately, to understand them, and to eventually make healthy decisions based on the information (Miller \& Cassady 2015). Interestingly, another study reported that younger consumers considered that product attributes that had implications on health were important (Kumar \& Kapoor 2017). Among consumers who do read nutrition labels, they would tend to pay more attention to food products with health claims on the label and were more likely to purchase that particular product (Steinhauser et al. 2019).

A study reported a strong relationship between nutrition label viewing and food purchase decisions. Nutrition labels were viewed more when the healthfulness of a product is 'ambiguous'; therefore, consumers spent more time viewing nutrition labels on 'meal' items such as soup, pizza and yogurt. It was also observed that consumers spent more time in viewing nutrition labels on food products they eventually purchased compared to foods that they decided not to purchase (Graham \& Jeffery 2011). Meanwhile, consumers who were pursuing specific dietary goals were seen to make more comparisons of nutrition labels before making purchase decisions. The more nutrition knowledge these consumers had and the more motivated they were in terms of their dietary goals, the more detailed they were in reading nutrition labels. Interestingly, knowledge on nutrition was found to be the middle agent that mediated between motivation of a healthier life and accuracy in the decision making process in terms of purchasing packaged food products (Miller \& Cassady 2012).

In Indonesia, interestingly, decisionmaking at the household level when it came to purchasing a food product was found to be dominated by non-nutrition aspects, such as socioeconomic status, family member requests, feelings about the food product, and the halal issue (Rachmi et al. 2018). Unfortunately, there is a lack of attention given to nutrition information on food labels, which was mostly due to the lack of good knowledge on nutrition (Kurnia et al. 2016). Stronger consumer attention has been placed on the halal logo and it has been identified as a major influence in purchase decision, especially among the younger generation (Siregar \& Alam 2018). Interestingly, the halal logo is actually not mandatory for all processed food products marketed in Indonesia as it is only required for certain products; whereas the items mandatory to be displayed on a food label are product name, ingredients list, net weight, name and address of manufacturer or importer, manufacturing date and code, expiry date, and permit number (Indonesia Food and Drug Authority 2018). And since 2019 , it has actually been mandatory for all processed food products marketed in Indonesia to have a nutrition information panel or nutrition label containing total energy, total fat, saturated fat, sugar and salt (sodium) content of the food product (Indonesia Food and Drug Authority 2019). However, there has been a lack of published reports that have addressed the issue of nutrition knowledge, nutrition label viewing, and purchase decision among consumers in Indonesia in order to get a better picture of the factors affecting their purchase behavior. Therefore, this study was conducted to investigate the relationship between the knowledge on nutrition labels and purchase behavior for packaged food products among consumers in Indonesia.

\section{METHODS}

\section{Design, location, and time}

This cross-sectional study was conducted in August-September 2018. The study was conducted in five different cities of three provinces (Jakarta, Bogor, Depok, Tangerang, Bekasi).

\section{Sampling}

400 male and female subjects from five different cities (Jakarta, Bogor, Depok, Tangerang, Bekasi) were selected to participate in this research. The number of subjects was calculated using the Slovin Formula based on the population of the five cities, which was $31,689,592$ people (Citisabc 2018) with a confidence level of $95 \%$ $(\alpha=0.05)$. In each city, 80 subjects were selected in supermarkets and public places using quota sampling. Subjects who were within the age range of 18-60 years, literate, and willing to participate in the study in these locations were included until a pre-determined number ( 80 subjects) was reached.

\section{Data collection}

Data were collected using a selfadministered questionnaire. There were four parts in the questionnaire, namely characteristics of subject (sex, age, occupation, education level, 
income), label reading behavior, knowledge on nutrition labels, and consumer purchase decision. Data on the frequency of reading labels and categories of food product labels checked were obtained to assess label reading behavior. There were 14 true-false questions on the components of food labels to assess knowledge on nutrition labels. Purchase decision was assessed through questions on concerns for purchasing, purchase decision for product with nutrition labels, and purchase decision for healthier products. Content validity of the questionnaire was approved by a panel of experts from the academia of IPB University and professionals from the Indonesia Food and Drug Authority and the WHO Country Office of Indonesia. The questionnaire was also tested for reliability, resulting in a Cronbach'sAlpha of 0.6 after it was pre-tested on 30 subjects with similar characteristics.

\section{Data analysis}

Data from the questionnaires were collected in accordance with the manual for data entry. With regards to knowledge on nutrition labels, each correct answer was scored as 1; while a wrong answer was scored as 0 , resulting in a total score of 0-14. Bivariate analyses using Spearman's Rank Correlation were conducted to correlate the characteristics of the subject on both knowledge on nutrition labels and purchase decision. Univariate, bivariate and multivariate (logistic regression) analyses were conducted using IBM SPSS Statistics Version 22.

\section{RESULTS AND DISCUSSION}

\section{Characteristics of subjects}

Among 400 subjects who participated in this study, 314 of them $(78.50 \%)$ were female. Furthermore, more than one-third were university students and employees $(37.5 \%$ and $36.0 \%$, respectively), while $59.8 \%$ of them were university graduates. Almost half of the respondents $(49.3 \%)$ had an income between IDR 500,000 and 2 million. The characteristics of the subjects are shown in Table 1.

\section{Label reading behavior}

According to Sumarwan (2011), the behavior of reading product labels is part of consumer behavior that will encourage them to buy, use, and evaluate a product. Previous studies

Table 1. Characteristics of subjects

\begin{tabular}{|c|c|c|}
\hline Characteristics of subjects & $\mathrm{n}$ & $\%$ \\
\hline \multicolumn{3}{|l|}{ Sex } \\
\hline Male & 86 & 21.5 \\
\hline Female & 314 & 78.5 \\
\hline Age (mean \pm SD) & \multicolumn{2}{|c|}{$27.8 \pm 9.8$} \\
\hline \multicolumn{3}{|l|}{ Occupation } \\
\hline University student & 150 & 37.5 \\
\hline Housewife & 102 & 25.5 \\
\hline Employee & 144 & 36.0 \\
\hline Unemployed & 4 & 1.0 \\
\hline \multicolumn{3}{|l|}{ Education level } \\
\hline Elementary school & 5 & 1.2 \\
\hline Junior high school & 26 & 6.5 \\
\hline Senior high school & 130 & 32.5 \\
\hline University & 239 & 59.8 \\
\hline \multicolumn{3}{|l|}{ Monthly income } \\
\hline$<$ IDR 500,000 & 26 & 6.5 \\
\hline IDR 500,000-2 millions & 197 & 49.3 \\
\hline >IDR 2-5 millions & 101 & 25.3 \\
\hline$>$ IDR 5-10 millions & 51 & 12.7 \\
\hline$>$ IDR 10 millions & 25 & 6.2 \\
\hline
\end{tabular}


show that the majority of consumers perform this activity before they buy or use a product/service (Kumalasari \& Sjafei 2013; Ruwani et al. 2014).

As shown in Table 2, results of this study showed that the majority of subjects rarely read food labels and only $25.3 \%$ stated that they read food labels frequently. This number is near to the result of a meta-analysis (Sumarwan et al. 2017), which reported that only about $30 \%$ of consumers frequently or often read product labels.

The type of food product also seemed to influence the consumer's label reading behavior. It is known from a previous study that people only commonly read the labels of certain food products (Ruwani et al. 2014). In this study, the types of food product nutrition labels that people commonly read and checked were milk and dairy products, beverages, and ready-toeat savories. The labels of these three types of products were commonly read and checked by 45 to $73 \%$ of subjects. The least read label was that of composite foods. Similarly, Sumarwan et al. (2017) reported that the labels of milk products were the most read label by the consumers, where the decision to read and check food labels was determined by exposure to advertisements, the internet, and knowledge gained from school.

\section{Knowledge on food and nutrition label}

As shown in Table 3, most $(74.8 \%$ and $63.0 \%$ ) of the subjects mentioned the halal logo and expiry date as components of a food label. More than half $(53.3 \%)$ of them were also familiar with list of ingredients. However, other components of a food label were less known by the subjects.

Among all the statements regarding food labels, the statement with the least number of correct answers was "all processed food products must have a nutrition label". The Indonesian Food and Drug Authority has recently made nutrition labels mandatory for all packaged food products

Table 2. Label reading behavior

\begin{tabular}{lcc}
\hline \multicolumn{1}{c}{ Label reading behavior } & $\mathrm{n}$ & $\%$ \\
\hline Frequency of reading food labels & 21 & 5.3 \\
Always & 101 & 25.3 \\
Often & 277 & 69.4 \\
Rarely & & \\
Product category of nutrition label checked & 294 & 73.5 \\
Milk and dairy products & 194 & 48.5 \\
Beverages & 183 & 45.8 \\
Ready-to-eat savories & 150 & 37.5 \\
Cereals and cereal products & 109 & 27.3 \\
Bakery products & 82 & 20.5 \\
Confectionery & 62 & 15.5 \\
Meat and meat products & 42 & 10.5 \\
Sweeteners & 38 & 9.5 \\
Fats, oils and emulsions & 37 & 9.3 \\
Fish and seafood products & 37 & 9.3 \\
Salts, spices, soups, sauces, salads, protein products & 23 & 5.8 \\
Edible ices & 19 & 4.8 \\
Fruits and vegetables, seaweed, nuts and seeds & 17 & 4.3 \\
Eggs and egg products & 7 & 1.8 \\
Composite foods & & \\
\hline
\end{tabular}


Nutrition label for processed food and purchase decision

Table 3. Knowledge on the components of a food label

\begin{tabular}{|c|c|c|}
\hline Components of food label & $\mathrm{n}$ & $\%$ \\
\hline Halal logo & 299 & 74.8 \\
\hline Expiry date & 252 & 63.0 \\
\hline List of ingredients & 213 & 53.3 \\
\hline Name of the product & 121 & 30.3 \\
\hline Net weight or net content & 56 & 14.0 \\
\hline Name and address of the manufacturer or importer & 56 & 14.0 \\
\hline Distribution permit number & 20 & 5.0 \\
\hline Date and code of production & 17 & 4.3 \\
\hline Origins of certain food ingredients & 9 & 2.3 \\
\hline
\end{tabular}

since 2019, while this study was conducted prior to when the regulation was enacted.

Almost all subjects $(95.8 \%$ and $92.0 \%$, respectively) understood the purpose of a nutrition label, which is to give information about the nutrient content of a product, and that sodium is essentially table salt. On the contrary, only about one-fourth of subjects had specific knowledge on the cut-off points for claims of specific nutrients, such as in the following statements: "a low fat product can only contain less than $3 \mathrm{~g} / 100 \mathrm{~g}$ of fat" and "sugar content may not be included in the nutrition label of a food product if the amount is less than $1 \mathrm{~g} /$ serving size". Similarly, only a low proportion of the subjects were aware that the statement "high fiber" is a nutrition claim (Table 4).

Table 5 shows that higher age $(\mathrm{r}=0.272$; $\mathrm{p}<0.001)$ and income $(\mathrm{r}=0.165 ; \mathrm{p}=0.001)$ of subjects was associated with better knowledge of nutrition labels. Similar results were found in Jackey et al. (2017) and Cannoosamy et al. (2014). This implies that older and wealthier subjects are more likely to be exposed to health or nutrition-related news.

\section{Purchase decision}

Table 6 shows that most $(69.5 \%)$ Indonesian consumers considered product price as the main determinant for purchase decision. This was also found in Indian and Hispanic consumers (Campbell 2013; Vemula et al. 2014; Kumar \& Kapoor 2017). More than onethird were also concerned about expiry date $(41.8 \%)$ and the halal logo (38.8\%). Among all the components of a food label, the expiry date was always checked by most of the consumers (Davies et al. 2010). Awareness of the halal logo was also seen in other Muslim countries, such as Malaysia (Muhamad et al. 2017). This study also found that about a third of Indonesian consumers were also concerned about the product's nutrition profile $(37.5 \%)$ prior to making a purchase. This number was quite similar to another study in India (Vemula et al. 2014). Nutrition awareness motivates consumers to read the nutrition profile before purchasing. This finding was not only seen among older adults who have to manage their diet in relation with the chronic diseases they have, such as hypertension and diabetes, but also among youths (Miller \& Cassady 2012; Kumar \& Anand 2016).

Most of the respondents (69.4\%) stated that they rarely read food labels, which is similar to the results of another study by Graham and Laska in 2012. Among the nutrition information provided on the label, Indonesian consumers were mostly concerned about fat, sugar, and protein. Similarly, Indian consumers were more concerned with information regarding fat and sugar (Vemula et al. 2014; Kumar \& Kapoor 2017). Among all food groups, most of the consumers $(73.5 \%)$ checked the nutrition profile of dairy products and analogues. The nutrition profile of beverages and ready-to-eat savories were also checked by almost half of consumers ( $48.5 \%$ and $45.8 \%$, respectively).

Almost all of the consumers $(96.0 \%)$ had decided to buy food products with nutrition labels because they considered them better than 
Mauludyani et al.

Table 4. Knowledge on nutrition labels

\begin{tabular}{clcc}
\hline No. & & \multicolumn{1}{c}{ Knowledge on nutrition labels } & n \\
\hline 1 & The purpose of a nutrition label is to give information about the nutrient content of a product (T) & 383 & 95.8 \\
2 & Sodium content represents the salt contained in a food product (T) & 368 & 92.0 \\
3 & $\begin{array}{l}\text { Energy, carbohydrate, protein, fat, and sodium are nutrients that are required to be included on a } \\
\text { nutrition label (T) }\end{array}$ & 354 & 88.5 \\
4 & Nutrition claims on a food product must be in accordance with the nutrient content of the product (T) & 320 & 80.0 \\
5 & Serving size is the amount of food normally consumed in one meal (T) & 290 & 72.5 \\
6 & The reference for nutrition labels in Indonesia is the Recommended Dietary Allowance (RDA) (T) & 275 & 68.8 \\
7 & The level of adequacy of daily nutritional needs is indicated by the percentage of RDA (T) & 260 & 65.0 \\
8 & The RDA has a similar value for all individuals (F) & 236 & 59.0 \\
9 & There are differences between nutrition claims and health claims (T) & 223 & 55.8 \\
10 & The statement "low fat" is a nutrition claim (T) & 214 & 53.5 \\
11 & Sugar content may not be included in the nutrition label if it is less than 1 g per serving size (T) & 110 & 27.5 \\
12 & A food product can be claimed as a low fat product if the fat content is less than 3 g per 100 g (T) & 100 & 25.0 \\
13 & The statement "high fiber" is not a nutrition claim (F) & 99 & 24.8 \\
14 & All processed food products must have a nutrition label (F) & 7.8 \\
\hline & Total score (mean \pm SD) & $7.7 \pm 2.3$ \\
\hline
\end{tabular}

T: True as correct answer; F: False as correct answer

similar products without nutrition labels. Most of them $(78.8 \%)$ also decided to buy more healthy products within a similar group of products. Nutrient claims of low fat $(28.7 \%)$ and low sugar $(22.6 \%)$ were considered healthier by consumers. Jacobs et al. 2011 also found that 'low in fat' was considered most important by about $70 \%$ of supermarket consumers in South Africa, which might indicate poor knowledge on nutrients in general.

Table 7 shows that knowledge of nutrition labels (OR=1.139; 95\% CI:1.016-1.276; $\mathrm{p}=0.025)$ and purchase decision on products with nutrition labels $(\mathrm{OR}=3.426$; 95\% CI:1.220-9.623; $\mathrm{p}=0.019$ ) were significantly associated with pur- chase decision for more healthy processed foods. Subjects with better knowledge on nutrition labels had higher awareness to choose products with nutrition labels compared to those without. Furthermore, based on their perceptions, they were able to select which products are considered healthier compared to other similar products. Subjects with better nutrition knowledge saw beyond the nutrition and health claims which later allowed them to make purchasing decisions (Steinhauser et al. 2019). Similar results were found in previous studies regarding maternal milk products (Damayanti \& Rimbawan 2016) and other various food products (Mhurchu et al. 2018).

Table 5. Association between the characteristics of subjects and knowledge on nutrition labels

\begin{tabular}{|c|c|c|}
\hline Characteristics of subjects & $\mathrm{r}$ & $\mathrm{p}$ \\
\hline Age & 0.272 & $<0.001^{*}$ \\
\hline Education level & 0.044 & 0.383 \\
\hline Income & 0.165 & $0.001^{*}$ \\
\hline
\end{tabular}

${ }^{\text {*Spearman's rank correlation } \mathrm{p}<0.05}$ 
Nutrition label for processed food and purchase decision Table 6. Concerns related to purchase decision, nutrition label and healthier products

\begin{tabular}{|c|c|c|}
\hline Purchase decision & $\mathrm{n}$ & $\%$ \\
\hline \multicolumn{3}{|l|}{ Concerns in making purchase decision } \\
\hline Price & 278 & 69.5 \\
\hline Expiry date & 167 & 41.8 \\
\hline Halal logo & 155 & 38.8 \\
\hline Nutrition profile & 150 & 37.5 \\
\hline Packaging & 119 & 29.8 \\
\hline Name of brand & 112 & 28.0 \\
\hline Taste & 94 & 23.5 \\
\hline Ingredients & 40 & 10.0 \\
\hline Preference & 38 & 9.5 \\
\hline Net weight & 26 & 6.5 \\
\hline Past experience & 13 & 3.3 \\
\hline BPOM logo & 8 & 2.0 \\
\hline \multicolumn{3}{|l|}{ Concern on components in a nutrition label } \\
\hline Fat & 221 & 55.3 \\
\hline Sugar & 179 & 44.8 \\
\hline Protein & 173 & 43.3 \\
\hline Carbohydrate & 130 & 32.5 \\
\hline Vitamin C & 85 & 21.3 \\
\hline Vitamin A & 84 & 21.0 \\
\hline Energy & 67 & 16.8 \\
\hline Sodium & 53 & 13.3 \\
\hline Calcium & 32 & 8.0 \\
\hline Iron & 12 & 3.0 \\
\hline Saturated fat & 7 & 1.8 \\
\hline Cholesterol & 4 & 1.0 \\
\hline Dietary fiber & 3 & 0.8 \\
\hline Purchase decision for product with nutrition label & 384 & 96.0 \\
\hline $\begin{array}{l}\text { Purchase decision for healthier products with a better nutrition profile compared to } \\
\text { other similar products }\end{array}$ & 314 & 78.5 \\
\hline \multicolumn{3}{|l|}{ Perception on what constitutes a healthier product } \\
\hline Low fat & 90 & 28.7 \\
\hline Low sugar & 71 & 22.6 \\
\hline High protein & 39 & 12.4 \\
\hline Balanced nutrition & 35 & 11.1 \\
\hline High calcium & 28 & 8.9 \\
\hline High vitamin & 16 & 5.1 \\
\hline Low sodium & 12 & 3.8 \\
\hline
\end{tabular}


Mauludyani et al.

Table 7. Factors associated with purchase decision for healthier food

\begin{tabular}{lccc}
\hline \multicolumn{1}{c}{ Factors } & OR & $95 \%$ CI & $\mathrm{p}$ \\
\hline Sex-female & 1.440 & $0.807-2.572$ & 0.218 \\
Age & 0.997 & $0.968-1.027$ & 0.841 \\
Education level-university & 0.884 & $0.520-1.501$ & 0.647 \\
Income >IDR 2 millions & 0.895 & $0.509-1.575$ & 0.702 \\
Frequent label reading & 0.894 & $0.270-2.965$ & 0.855 \\
Knowledge on nutrition label & 1.139 & $1.016-1.276$ & $0.025^{*}$ \\
Concerned about nutrition labels for purchase decision & 1.238 & $0.717-2.138$ & 0.443 \\
Concerned about fat in nutrition profile & 1.231 & $0.748-2.026$ & 0.414 \\
Concerned about sugar in nutrition profile & 0.813 & $0.487-1.356$ & 0.427 \\
Concerned about sodium in nutrition profile & 1.159 & $0.558-2.407$ & 0.691 \\
Purchase decision on products with nutrition labels & 3.426 & $1.220-9.623$ & $0.019^{*}$ \\
\hline
\end{tabular}

${ }^{*}$ Logistic regression $\mathrm{p}<0.05 ; \mathrm{r}^{2}=0.427$

\section{CONCLUSION}

The knowledge on food and nutrition labels of Indonesian consumers was still poor. Most consumers considered product price prior to making a purchase decision. Consumers were also concerned about expiry date, the halal logo and nutrition facts presented on the label. In terms of nutrition labels, consumers in Indonesia were mostly concerned about fat, sugar, and protein. Almost all of the consumers chose products with nutrition labels than products without. Most had also decided to buy more healthy products, which was deemed as low in fat and sugar. Higher knowledge regarding nutrition labels and purchase decision on products with nutrition labels was significantly associated with purchase decision for more healthy processed food. This study suggests the importance of programs aimed at increasing the awareness of consumers relating to nutrition labels and claims in order to have an optimum impact in achieving the objective of public policy related to food, nutrition, and health.

\section{ACKNOWLEDGEMENT}

The authors wish to thank the World Health Organization Country Office for Indonesia, represented by Sugeng Eko Irianto, who sponsored the funding of this study and was involved in designing the study. Appreciation is also given to the Directorate of Processed Food Standardization, Indonesia Food and Drug Authority that were involved in the planning of the study and data collection.

\section{AUTHOR DISCLOSURES}

The authors declare that there is no conflict of interest with other person or institution.

\section{REFERENCES}

Campbell J. 2013. Antecedents to purchase intentions for Hispanic consumers: A“local" perspective. Int Rev Retail Distrib Consum Res 23(4):440-455. https://doi.or g/10.1080/09593969.2013.796565.

Cannoosamy K, Pugo-Gunsam P, Jeewon R. 2014. Consumer knowledge and attitudes toward nutritional labels. J Nutr Educ Behav 46(5):334-340. https://doi. org/10.1016/j.jneb.2014.03.010.

Citisabc. 2018. Jakarta. Citisabc. https://www. citiesabc.com/city/jakarta/ [Accessed 9th February 2021].

Damayanti R, Rimbawan R. 2016. Pengetahuan, persepsi, dan sikap ibu hamil terhadap klaim gizi kaitannya dengan keputusan pembelian produk susu ibu hamil. J Gizi Pangan 11(1):1-8.https://doi. org/10.25182/jgp.2016.11.1.\%p. 
Davies P, MacPherson K, Froud E. 2010. Evidence review of public attitude towards and use of general food labelling. http:// citeseerx.ist.psu.edu/viewdoc/download; sessionid $=956 \mathrm{DE} 357 \mathrm{C} 4 \mathrm{~B} 45410 \mathrm{~F} 288 \mathrm{E} 2 \mathrm{~A}$ FAB94A660?doi $=10.1 .1 .557 .8405 \& \mathrm{rep}=\mathrm{r}$ ep1\&type $=$ pdf $[$ Accessed 12th September 2020].

Graham DJ, Jeffery RW. 2011. Location, location, location: Eye-tracking evidence that consumers preferentially view prominently positioned nutrition information. J Am Diet Assoc 111(11):1704-1711. https:// doi.org/10.1016/j.jada.2011.08.005.

Graham DJ, Laska MN. 2012. Nutrition label use partially mediates the relationship between attitude toward healthy eating and overall dietary quality among college students. J Acad Nutr Diet 112(3):414-418. https:// doi.org/10.1016/j.jada.2011.08.047.

Indonesia Food and Drug Authority. 2018. Peraturan Badan Pengawasan Obat dan Makanan Nomor 31 Tahun 2018 Tenatng Label Pangan Olahan. Jakarta (ID): BPOM RI.

Indonesian Food and Drug Authority. 2019. BPOM Regulation Number 22 Year 2019 about Nutritional Value Information on Processed Food Labels. Jakarta (ID): BPOM RI.

Jackey BA, Cotugna N, Orsega-Smith E. 2017. Food label knowledge, usage and attitudes of older adults. J Nutr Gerontol Geriatr 36(1):31-47. https://doi.org/10.1080/2155 1197.2017.1280868.

Jacobs SA, de Beer H, Larney M. 2011. Adult consumers' understanding and use of information on food labels: A study among consumers living in the Potchefstroom and Klerksdorp regions, South Africa. Public Health Nutr 14(3):510-522. https://doi. org/10.1017/S1368980010002430.

Kumalasari H, Sjafei NJ. 2013. Analyzing the effect of health and appearance consciousness on intention to calculate calorie information if displayed at fast food restaurant menu. Journal of Business Strategy Execution 5(2):104-130.

Kumar N, Anand S. 2016. The attitude of Indian youth toward nutrition: Factors, segments, and implications. J Food Prod Mark 22(8):967-985. https://doi.org/10.1080/10 454446.2015.1121421.
Kumar N, Kapoor S. 2017. Do labels influence purchase decisions of food products? Study of young consumers of an emerging market. Br Food J 119(2):218-229. https:// doi.org/10.1108/BFJ-06-2016-0249.

Kurnia P, Wardhani DTK, Hariyani R. 2016. Consumer attitudes, nutrition knowledge, and use of nutrition information on the labels of packaged drinks among adolescents in Surakarta, Indonesia. Proceeding International Conference on Health and Well-Being (page 253-264), 27-28th May. Surakarta (ID): Faculty of Health Science \& Faculty of Psychology Universitas Muhammadiyah Surakarta.

Mhurchu CN, Eyles H, Jiang Y, Blakely T. 2018. Do nutrition labels influence healthier food choices? Analysis of label viewing behaviour and subsequent food purchases in a labelling intervention trial. Appetite 121:360-365. https://doi.org/10.1016/j. appet.2017.11.105.

Miller LMS, Cassady DL. 2012. Making healthy food choices using nutrition facts panels. The roles of knowledge, motivation, dietary modifications goals, and age. Appetite 59(1):129-139. https://doi. org/10.1016/j.appet.2012.04.009.

Miller LMS, Cassady DL. 2015. The effects of nutrition knowledge on food label use. A review of the literature. Appetite 92:207-216. https://doi.org/10.1016/j. appet.2015.05.029.

Muhamad N, Leong VS, Md Isa N. 2017. Does the country of origin of a halal logo matter? The case of packaged food purchases. Review International Business and Strategy 27(4):484-500. https://doi. org/10.1108/RIBS-06-2017-0049.

Rachmi CN, Hunter CL, Li M, Baur LA. 2018. Food choices made by primary carers (mothers/grandmothers) in West Java, Indonesia. Appetite 130:84-92.https://doi. org/10.1016/j.appet.2018.08.005.

Ruwani A, Retnaningsih R, Simanjuntak M. 2014. Nilai dan tipe konsumen rumah tangga dan kaitannya dengan perilaku pembelian produk makanan kemasan. Jurnal Ilmu Keluarga Konsumen 7(1):48-57. https:// doi.org/10.24156/jikk.2014.7.1.48.

Siregar R, Alam A. 2018. Halal label on food products by MUI (Indonesian Ulama 
Council) and students purchasing decision of Faculty of Business and Economic Universitas Muhammadiyah Surakarta. Journal of Islamic Economic Laws 1(1):1-30. https://doi.org/10.23917/jisel. v1i1.6163.

Steinhauser J, Janssen M, Hamm U. 2019. Who buys products with nutrition and health claims? A purchase simulation with eye tracking on the influence of consumers' nutrition knowledge and health motivation. Nutrients 11(9):2199. https:// doi.org/10.3390/nu11092199.
Sumarwan U. 2011. Perilaku Konsumen. Bogor (ID): Ghalia Indonesia.

Sumarwan U, Simanjuntak M, Yuliati LN. 2017. Meta-analysis study: Reading behavior of food products label. Journal Consumer Sciences 2(2):26-40. https:// doi.org/10.29244/jcs.2.2.26-40.

Vemula SR, Gavaravarapu SM, Mendu VVR, Mathur P, Avula L. 2014. Use of food label information by urban consumers in India-a study among supermarket shoppers. Public Health Nutr 17(9):21042114. doi:10.1017/S1368980013002231 